\title{
USE OF BIO-WATER AS SOCIAL TECHNOLOGY FOR SEMI-ARID REGIONS
}

\author{
José Adailton Lima Silva \\ Universidade Federal de Pernambuco, Departamento de Ciências Geográficas \\ Pós-Graduação em Geografia, Recife/PE, Brasil \\ adailton limasilva@hotmail.com \\ Thaís Mara Souza Pereira \\ Universidade Federal de Pernambuco, Departamento de Ciências Geográficas \\ Pós-Graduação em Geografia, Recife/PE, Brasil \\ thaismara estrela@hotmail.com \\ Pedro Vieira Azevedo \\ Universidade Federal de Campina Grande, Unidade Acadêmica de Ciências Atmosféricas \\ pvdeazevedo@gmail.com
}

\begin{abstract}
Water scarcity in the Brazilian semi-arid region has inhibited agricultural activity due to large declines in production, especially food. Currently, Bioágua is used as a technology to manage gray water and irrigate agricultural crops. Therefore, the present study analyzed the use of Bioágua to manage domestic effluents in the promotion of irrigation of cultivars, and evaluated the social, economic and environmental benefits derived from this technology. For that, exploratory and qualitative research was carried out with the rural families in the municipality of Pedra Lavrada-PB, semi-arid region of Paraíba. With the studies, it was possible to identify that the bio-water: 1) is a simple technology, of easy construction and of low cost; 2) provide water security to promote irrigation of various crops; 3) made possible the management of water resources available locally; and 4) does not cause environmental impacts and, mainly, inhibits the pollution of the soil and of adjacent water courses. Finally, it was observed that the bio-water is a socially disseminable, economically viable and environmentally correct technology.
\end{abstract}

Keywords: Water scarcity. Domestic effluents. Irrigation of crops. Social Technologies.

\section{USO DE BIOÁGUA COMO TECNOLOGIA SOCIAL PARA REGIÕES SEMIÁRIDAS}

\section{RESUMO}

A escassez hídrica no semiárido brasileiro tem inibido a atividade agrícola por causar grande declínio da produção, principalmente de alimentos. Atualmente, utiliza-se o Bioágua como tecnologia para gerir as águas cinzas e irrigar as culturas agrícolas. Neste sentido, o presente estudo analisou o uso do Bioágua para gerenciar efluentes domésticos na promoção da irrigação de cultivares e avaliou os benefícios sociais, econômicos e ambientais derivados dessa tecnologia. Para tanto, foram realizadas pesquisas exploratórias e qualitativas com as famílias rurais do município de Pedra Lavrada-PB, região semiárida da Paraíba. Com os estudos, foi possível identificar que a bioágua: 1) é uma tecnologia simples, de fácil construção e de baixo custo; 2) fornece segurança hídrica para promover a irrigação de várias culturas; 3) possibilitou a gestão dos recursos hídricos disponíveis localmente; e 4) não causa impactos ambientais e, principalmente, inibe a poluição do solo e dos cursos d'água adjacentes. Por fim, observou-se que o Bioágua é uma tecnologia socialmente disseminável, economicamente viável e ambientalmente correta.

Palavras-chave: Escassez hídrica. Efluentes domésticos. Irrigação de cultivos. Tecnologias sociais.

$\begin{array}{llllll}\text { Caminhos de Geografia } & \text { Uberlândia } & \text { v. 20, n. } 72 & \text { Dez/2019 } & \text { p. 242-250 Página } 242\end{array}$




\section{INTRODUCTION}

The Brazilian semi-arid is characterized by high average annual temperatures, high evapotranspiration index and, mainly, low rainfall index. Due to this climatic scenario, agriculture - especially family farming - has been made unfeasible, since climatic conditions have caused large declines in agricultural production, which directly affected the quality of life of thousands of rural families in the Brazilian semi-arid region.

In light of the above, there are currently technologies aimed to locally available water resources to promote irrigated agriculture. In this sense, a few years ago came the bio-water: a simple technique that makes possible the use of gray water for food production. Thus, the bio-water has contributed to both the food security of the families and to the sustainability of agricultural production in the semi-arid region (SANTOS et al., 2016).

In view of the context described, the objective was to analyze the social, economic and environmental benefits of using the bio-water in the semiarid scenario. In order to reach the proposed objective, an exploratory and qualitative research was carried out with the rural families in the city of Pedra LavradaPB, in the semi-arid region of Paraíba, seeking to identify some indicators: i) construction methods of the bio-water; ii) socioeconomic viability of the bio-water; iii) relevance of the bio-water to the quality of life of local families; and iv) what social, economic and environmental improvements come from the use of the bio-water.

The choice of the municipality of Pedra Lavrada-PB was due to the fact that it had some aspects: 1) a large part of the rural population does not have basic sanitation, which contributes to the emergence of diseases/problems related to water supply; b) many rural families suffered, during the long dry season, large losses in agricultural production, which reduced local family income; and c) many local families have used the bio-water to promote the irrigation of cultivars and, consequently, to produce more grains and food.

It is important to emphasize that the present research became justifiable as it sought to investigate: to what extent the bio-water can be considered a simple and disseminable technique? Do the costs involved in the construction/maintenance of the bio-water make it economically viable? And what problems or benefits come from the use of bio-water by rural families? Thus, to give plausible answers to the aforementioned questions, was what motivated the referent study.

In addition to the aforementioned, this research will contribute with technical and theoretical knowledge about how the bio-water has become an efficient social technology for the use of gray water in the promotion of agricultural production.

Finally, it is known that gray water can cause several socio-environmental problems, such as: proliferation of pathogens and vectors of diseases, eutrophication of water bodies, and soil contamination. Thus, it is of great importance to analyze the benefits to the farmer from the use of gray water through the bio-water (OLIVEIRA et al., 2017).

\section{THEORETICAL FOUNDATION}

\section{NORTHEASTERN SEASON: WATER SHORTAGE, FALL OF AGRICULTURAL PRODUCTIVITY AND REUSE OF GRAY WATERS}

The Brazilian semi-arid, with an area around 1 million $\mathrm{km}^{2}$ and a population of about 20 million inhabitants, is one of the largest and most densely inhabited in the world; almost half of this population is still rural and has the lowest average income in Brazil, as well as the country's worst economic and social indicators (SAMPAIO et al., 2005).

Regarding climatic conditions, the Brazilian semi-arid region is characterized by: low rainfall indexes, space-time variability of rains, high annual average temperatures, and high rates of evapotranspiration. In this region, long periods of drought, commonly known as drought, are common. Therefore, the drought is a natural phenomenon that has generated social and economic difficulties for families in the Brazilian semi-arid region, as long periods of drought make agriculture and livestock development unfeasible, activities that are essential for the generation of family income of local families (GAMA et al., 2013).

The Brazilian semi-arid region presents itself as "a remarkable semiarid pocket, dominated by the BSh climate; This is a complex geographic space of a seasonal nature that has a series of environmental and socioeconomic problems, often due to climatic adversities (JATOBÁ, 2012). In this sense, it is enough to remember that the semi-climatic climatic conditions in the Northeast of Brazil have contributed to the decline of agricultural production and, consequently, has promoted a decrease in employment and income in the countryside.

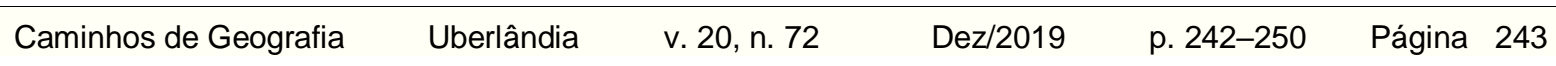


In view of the above, the fact is that semiarid climatic conditions have increased the risks of agricultural activity, increasing the socioeconomic vulnerability of local families, and increasing the rural exodus of numerous agricultural families. Regarding agricultural activity, Gama et al. (2012) state that: droughts hit plantations and harvests, which reduces the supply of food, jeopardizes the feeding of thousands of people, and generates hunger and misery in the countryside.

In view of the above, numerous technologies have been implemented in the Brazilian semi-arid region with the objective of promoting the management of the water resources available locally. Therefore, the use of bio-water as a simple technology to promote the reuse of gray water in small crops has been sought, which has contributed to the greater supply of water, besides contributing to the production of food and / or fodder for the animals.

The bio-water consists of a process of filtration by mechanisms of physical and biological impediment of the residues present in gray water, where the organic matter is biodegraded by a population of microorganisms and earthworms - Eisenia fetida (SANTIAGO et al., 2015). With the digestion and absorption of organic matter, which is retained in the water by the worms, the removal of its main pollutants occurs (POBLETE, 2010).

According to Santos et al. (2016), bio-water is a simple technology that allows the reuse of gray water as an alternative for food production and reduction of environmental contamination in the backyards of the farming families of the Brazilian semi-arid region.

In the Brazilian semi-arid, there are already many initiatives and projects that use gray water for the irrigation of vegetables, roots, fruits and food. Therefore, it is important to remember that these practices occur in compliance with the current legislation that determines the pretreatment of gray water, which are classified as "effluents derived from domestic or commercial use exclusively of showers, bathroom sinks, bathtubs, tanks and washing clothes (BRASIL, 2005). According to Santiago et al. (2015), the bio-water is an efficient and safe technique, since numerous surveys carried out by the Dom Helder Câmara Project (SDT-MDA / FIDA / GEF), conducted by the Federal Rural Semiarid University - UFERSA - and its partners, presented the following results:

a) The behavior of plants under post-treatment water irrigation follows normal patterns of plant growth and development;

b) The physical and chemical properties of the soil irrigated with the post-treatment water present normal standards for agricultural use;

c) The chemical properties of the water after treatment meet the parameters required for agricultural use. Reuse water has good amounts of nutrients and was not a source of environmental pollution;

d) The bio-water System has the potential to reduce global E. coli from 4 to 7 log units, meeting the health goal mentioned by the World Health Organization (WHO) for gray water.

e) Water does not produce bad smell due to the biological processes used, avoiding the situation of "open sewage"; and

f) The bio-water system presents a low cost of implantation and maintenance (the cost of energy is insignificant), having its operation carried out by the own families;

It is important to note that:

The relationship of the food, economic and environmental crises has worried the human populations, especially regarding the conditions of guarantee of food and nutritional security, which, in turn, refers to the availability of food in ideal quantity and quality, as well as to the forms of production and food consumption (SANTOS et al., 2016, p 104).

Thus, it is imperative to promote means and techniques that promote the rational use of water resources in food production. In view of this, the bio-water has proved to be a practical mechanism for the promotion of agricultural production, which makes it a technology that can and should be studied/improved to improve the living conditions of many families living with water scarcity in the semi-arid Brazilian.

\section{MATERIALS AND METHODS RESEARCH SPACE}

The present work was carried out in the rural area of the municipality of Pedra Lavrada (Latitude 06 ${ }^{\circ} 45^{\prime} 25$ "S, Longitude $36^{\circ} 28^{\prime} 49^{\prime \prime} \mathrm{W}$ and Altitude: 516 meters), located in the micro-region of the eastern Seridó of the state of Paraíba (Figure 1). This municipality is located about $230 \mathrm{~km}$ away from the capital of Paraíba, João Pessoa, and is limited to the municipalities of Nova Palmeira (to the

\begin{tabular}{lllll}
\hline Caminhos de Geografia $\quad$ Uberlândia & v. 20, n. 72 & Dez/2019 & p. 242-250 Página 244
\end{tabular}


north), Cubati and Seridó (to the south), with Sossego and Baraúnas (to the west), and with the state of Rio Grande do Norte (to the east), covering an area of $351 \mathrm{~km}^{2}$ and a population of 7,475 (IBGE, 2010).

Figure 1 - Location of the municipality of Pedra Lavrada - PB in the State of Paraíba.

\section{Location of the municipality of Pedra Lavrada, State of Paraíba, Brazil}
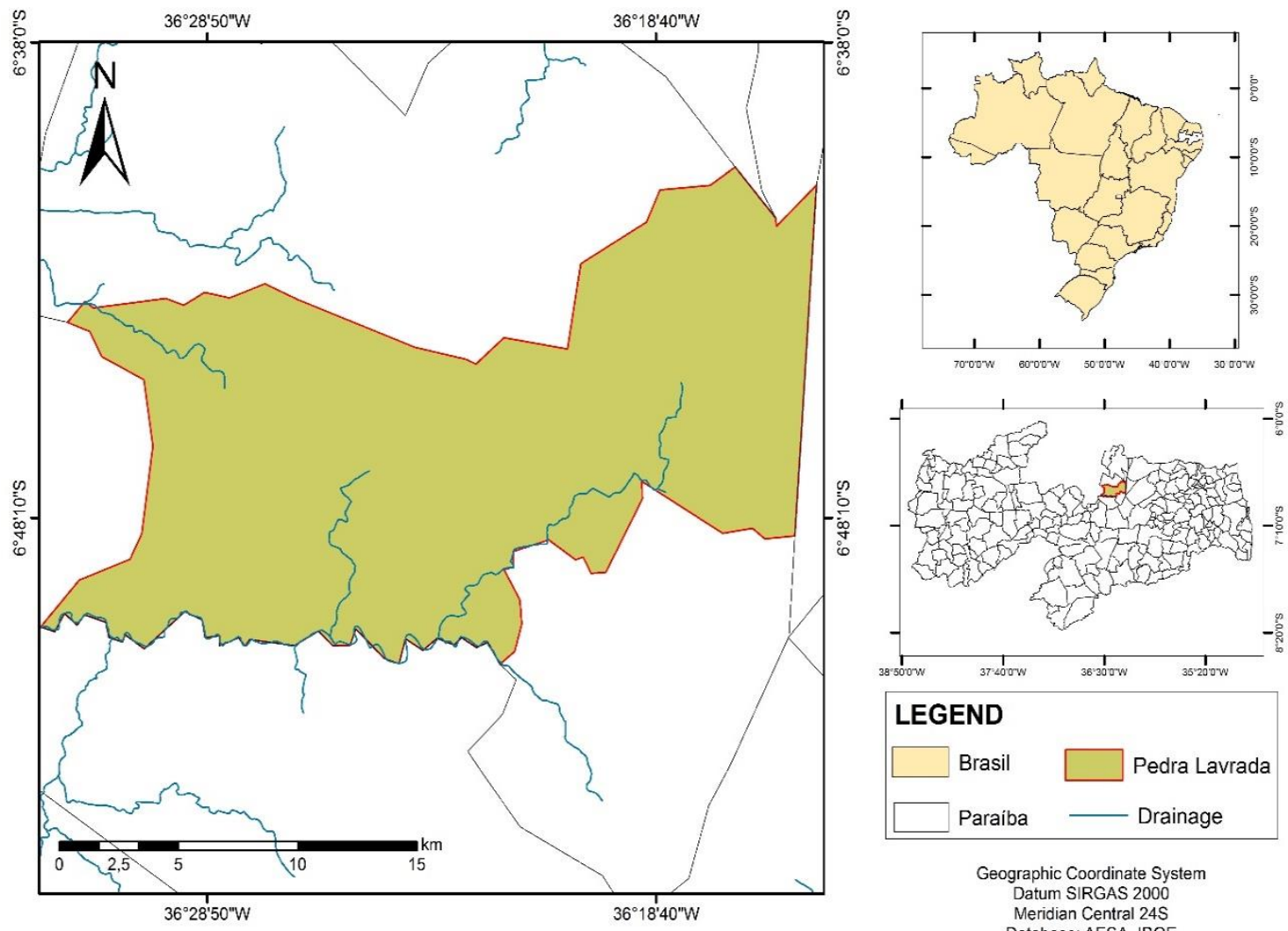

Geographic Coordinate System

Prepared by the authors/2018.

Regarding socioeconomic aspects, the municipality has an HDI of 0.574 and a GDP of R $\$ 30,364$, which is derived from the economic activities of the primary (11\%), secondary (12) and tertiary $(77 \%)$ sectors. Also, regarding the physical aspects, according to the CPRM (2005), the municipality of Pedra Lavrada-PB presents:

1. Geology and Geomorphology: Pedra Lavrada-PB is inserted in the geo-environmental unit of the Borborema Plateau. In the municipality, the average altitude is 500 meters. The relief is gently undulating. When it comes to soil fertility, it is quite varied, with a certain predominance from average to high;

2. Climate and vegetation: the local climate is of the hot and dry tropical type, conditioning the characteristics of the semi-arid climate: high average annual temperatures, high evapotranspiration index, low rainfall index, and spatial and temporal variation of rainfall. As a result of these climatic conditions, we can observe the native vegetation of the Caatinga: vegetation with low trees and shrubs, which usually lose leaves during the dry season (deciduous species), in addition to many xerophytic species (CPRM, 2005);

3. Hydrography: The municipality of Pedra Lavrada-PB is located in the areas of the Piranhas River basin, more specifically in the sub-basin that comprises the Seridó River. Affluent streams besides being periodic, they have a small outflow, and groundwater potential is low (CPRM, 2005). 
The choice of the municipality of Pedra Lavrada-PB as a research space, was due to the fact that it presented some criteria essential to this research, such as: 1) a large part of the local rural population is low income; 2) the costs of buying kitchen gas have become a limiting factor in family income; and 3 ) there are numerous families that have in the biodigestor their main source of energy for cooking food. Thus, it has become essential to analyze the socioeconomic and environmental benefits of biodigesters. For that, some methodological procedures were used, which will be described next.

\section{METHODOLOGICAL PROCEDURES}

Currently, in several parts of the world, there are several models of bio-water, which have been developed and adapted to look for an increase of the efficiency of these systems along with a reduction of equipment costs. In this work, the bio-water model (Figure 2) proposed by the Dom Helder Câmara Project (SDT-MDA/FIDA/GEF), carried out by the Non-Governmental Organization, ATOS (Advice, Consultancy and Sustainable Technical Guidance) and the Federal Rural University of the Semi-Arid -UFERSA. The said model of biowater consists of:

1) Biological filter: it is a masonry tank, with capacity to store 400 liters, constructed with cement premolded, where humus, earthworm, and saw of wood are placed to carry out the filtration and decomposition of residues present in the gray waters;

2) Reuse tank: it is made up of another masonry tank - also capable of storing 400 liters - which serves to store the gray water that has been filtered in the previous stage;

3) Irrigation system: consists of a small drip irrigation system composed of: a centrifugal electric motor pump of $1 / 2 \mathrm{CV}$; and $16 \mathrm{~mm} \mathrm{DN} 16$ drip hose to irrigate crops.

In summary, the bio-water is a simple technology that consists of a system of collecting the gray water of residences tata are filtered through the use of saw dust, washed sand, gravel and pebbles; (Eisenia foetida) for the decomposition of the organic compounds present in gray waters (DOMBROSKI et al., 2013). After this treatment process, the water is reused in the drip irrigation of various types of crops.

Figure 2 - Schematic drawing of the bio-water installation.

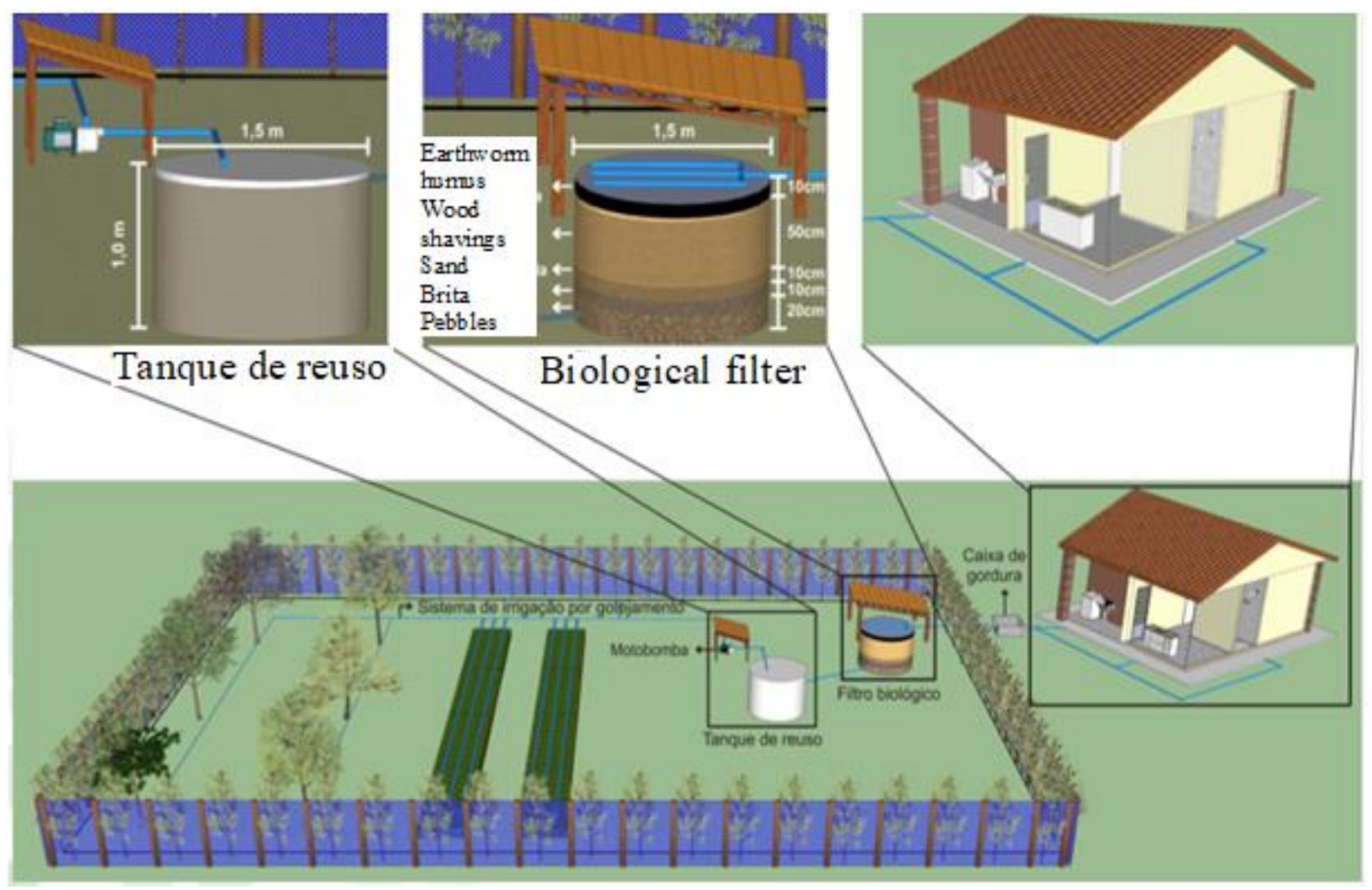

Source - Brazil, 2017. 
Regarding the processes, an exploratory study based on in situ studies was carried out, after analyzing the theoretical and methodological foundations, where, through the icnographic record, the aim was to identify the ways of constructing the bio-water, as well as the management and use of the bio-water.

In addition to the above, a participatory research was carried out with the rural families that use the bio-water, in order to analyze the importance of this technology and, mainly, to investigate the social, economic and environmental benefits arising from the use of the bio-water. Finally, with the qualitative studies performed, significant results were obtained, which will be described next.

\section{RESULTS AND DISCUSSIONS}

At first, in the rural area of the municipality of Pedra Lavrada-PB, the construction of bio-waters (Figure 3) was identified in local communities that coexist with periodic water shortages.

Figure 3 - Biohazards installed in rural communities in the municipality of Pedra Lavrada-PB.

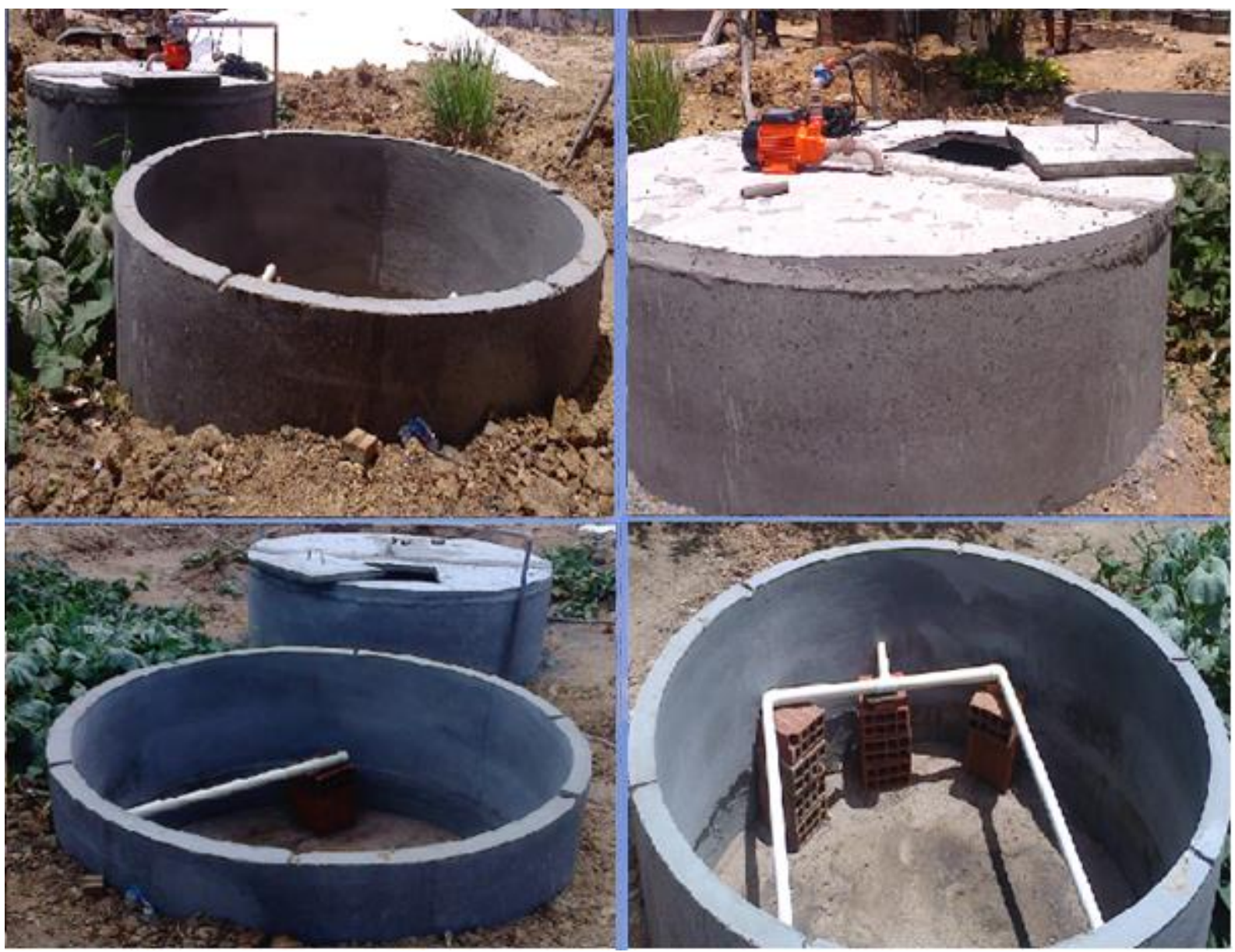

Source - Author's photo/2018.

After the identification of the bio-waters, it was observed the system of capture and use of the gray waters for the irrigation of the cultivars. Thus, it was identified that: the gray water from the sinks (kitchen and laundry), shower, tank or washing machine (Figure 4-A) is channeled to the tank (Figure 4-B) containing a two-layer filter of organic material such as humus and sawdust, and two layers of inorganic material: gravel, gravel and pebble. After filtration in the first tank, the water flows to the reuse tank (Figure 4-C), where the water is stored and subsequently pumped for irrigation of the beds with various crops (Figure 4-D). 
During the on-site surveys, it was realized that the Bio-water is considered by the local families as a simple and viable technology, since it is easy to construct - the families themselves build the bio-water - and of low economic cost: on average $R \$ 1,500.00$ reais.

With the use of the bio-water, a daily production of 120 liters was obtained, which allowed the drip irrigation of several local crops: coconut and orange plantations, vegetables, lettuce, herbs, and palm feedingstuffs.

Figure 4 - System of use of the bio-water installed in the city of Pedra Lavrada-PB.

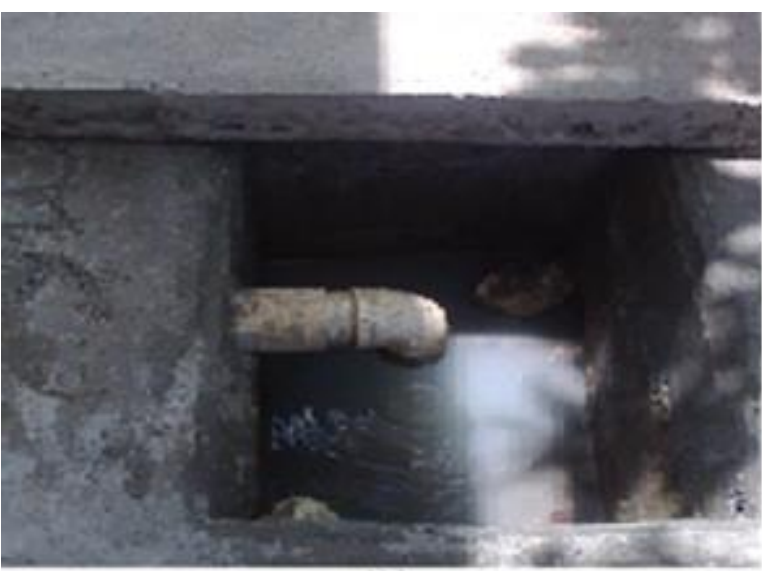

(A)

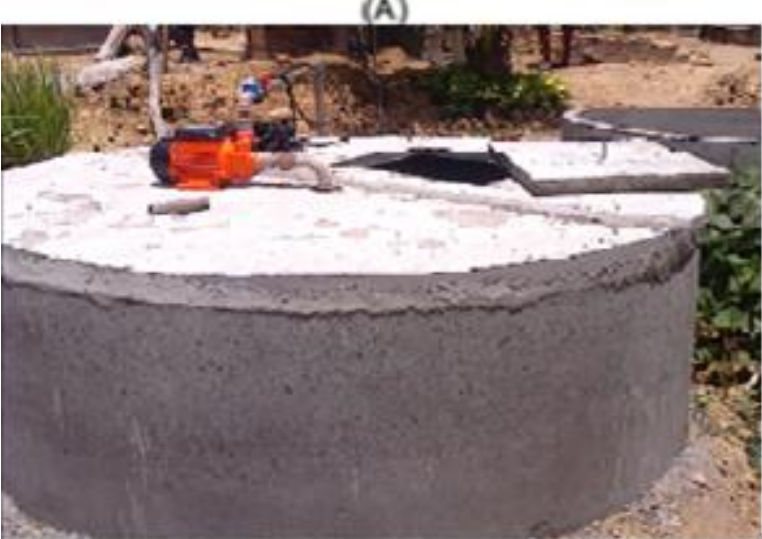

(C)

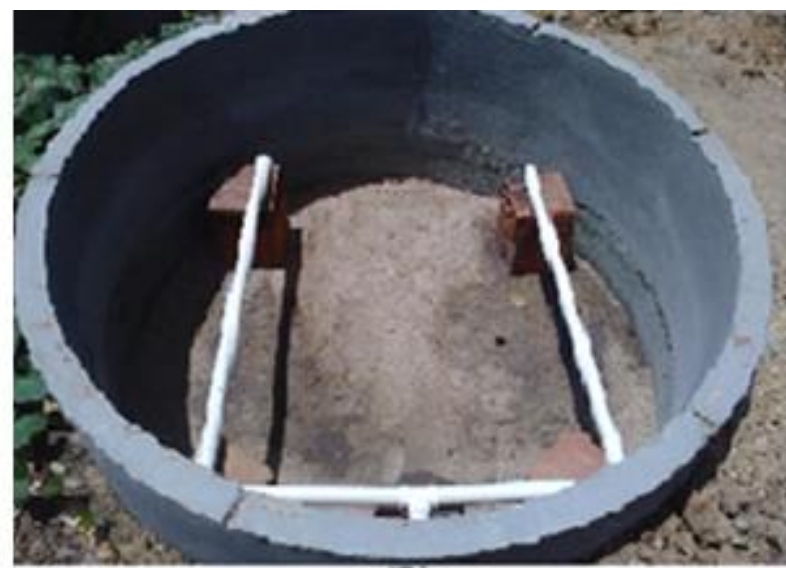

(B)

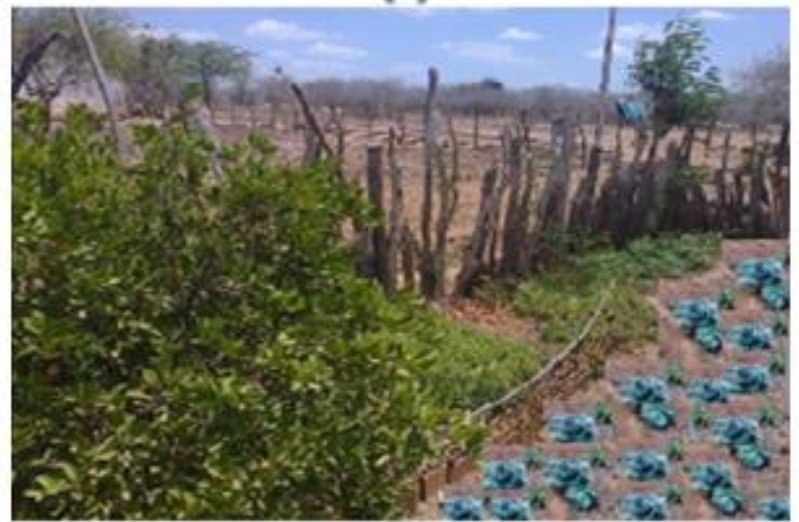

(D)

Source - Author's photo/2018.

Thus, it being understood that the water scarcity provided by the climatic conditions has affected agricultural production, it was observed that the use of bio-water became of applicable and relevant, since this technology enabled not only agricultural production but also the production of fodder, which contributes to the permanence of agropastoral activity, even under adverse climatic conditions.

Thus, Bio-Agua is a Social Technology- TS that coexists with the semi-arid region since, according to Gouveia (2015) it is characterized as a "living system" through a biological filtration and drip irrigation system. This TS therefore reuses gray or served waters (bath water, sinks, tanks, washing machines, etc.), for use in family agriculture.

In summary, the following social, economic and environmental benefits were observed: a) management of water resources available locally; b) water security for irrigation of cultivars; c) production of feed and animal fodder; d) is a simple technology, low cost and easy to build, which allows its social dissemination; e) treats the ash in a natural way, without adding chemicals; and f) inhibits contamination of soil, watercourses or possible environmental problems due to undue disposal of domestic effluents.

In view of the above, it may be emphasized that: 
Bio-water presents itself as an agrifood alternative suitable for family-based agriculture, based on the valorization of local resources, on the autonomy of farmers, making them the main subjects in the process of food production, water reuse, conservation of soil. (SANTOS et al., 2016, p.102).

Finally, it could be observed that the bio-water is a simple technology that can provide the reuse of gray water and, with this, to enable the improvement of the quality of life of rural agricultural families that coexist with water scarcity in the Brazilian semi-arid region.

\section{FINAL CONSIDERATIONS}

With the accomplishment of the studies, it was concluded that the bio-water: 1) is a simple technology, of low cost and of easy construction, which allows its dissemination in the most diverse Brazilian rural communities; 2) provided socioeconomic and environmental benefits related to water management for irrigation of cultivars; 3) provides water security for forage production; and 4) inhibited environmental contamination - soil, waterways, etc.

It is important to note that, due to the advantages and beneficial socioeconomic and environmental benefits that the Bio-water can provide, it must be understood that it can present a disadvantage in terms of its implantation and management, because according to Santiago et al. (2015), the Bio-water has in some cases the following problems: i) the population's rejection of this practice, due to the lack of knowledge that it is possible to use it safely, or due to cultural resistance; (ii) improper use can lead to risks of disease transmission to gray water workers/handlers; and iii) there is the possibility of changes salinization of the soil, and damage to crops when the irrigation system is poorly managed.

However, it is essential to understand Bio-water as a social technology capable of efficiently managing gray water, and especially of promoting the water security necessary for agricultural production in semi-arid regions.

Finally, it was observed that the technology of Bioágua fits in the concept of a TS, being of easy construction or replication, economically feasible and effective in the use in the agriculture of the families.

\section{AGRADECIMENTOS}

Agradecemos a Coordenação de Aperfeiçoamento de Pessoal de Nível Superior- CAPES, e a Fundação de Amparo à Ciência e Tecnologia de Pernambuco (FACEPE) pelo auxílio no fornecimento de recursos financeiros às pesquisas realizadas.

\section{BIBLIOGRAPHICAL REFERENCES}

BRASIL. Conselho Nacional de Recursos Hídricos. Resolução №54 - Estabelece modalidades, diretrizes e critérios gerais para a prática de reúso direto não potável de água, e dá outras providências. Diário Oficial da União, 9 mar. 2005.

BRASIL. Ministério do Desenvolvimento Agrário. Projeto Dom Elder Câmara. Disponível em: https://www.projetodomhelder.gov.br/site. Acessado em: 13 de julho de 2017.

CPRM - Serviço Geológico do Brasil- Projeto cadastro de fontes de abastecimento por água subterrânea. Diagnóstico do município de Pedra Lavrada, estado da Paraíba / Organizado [por] João de Castro Mascarenhas, Breno Augusto Beltrão, Luiz Carlos de Souza Junior, Manoel Julio da Trindade G. Galvão, Simeones Neri Pereira, Jorge Luiz Fortunato de Miranda. Recife: CPRM/PRODEEM, 2005.

DOMBROSKI, S. A. G.; SANTIAGO, F. dos S. ; JALFIM, F. T. ; DIAS, I. C. G. M. Eficiência de tratamento de água cinza pelo bioágua familiar. In: Encontro Internacional das Águas, $7^{\circ}, 2013$, Recife. Gestão de Água: Água, Meio-Ambiente e Saúde. Recife: FASA, 2013. p. 170-177.

GAMA, C.M.; SILVA, J.A.L.; MEDEIROS, M.C.S. ; FREITAS, J.; DAMASCENO, J. SECAS: uma tragédia socioeconômica. In: I Workshop Internacional sobre Água no Semiárido Brasileiro, Universidade Federal de Campina Grande, Campina Grande, 2013. 
GOUVEIA, A. R. Manual de Utilização - Sistema de Bioágua Familiar - Projeto de Segurança Alimentar para o Semiárido de Pernambuco (Cartilha), Recife, out/2015.

IBGE - Censo demográfico 2010 (Instituto Brasileiro de Geografia e Estatística). Disponível em:< https://cidades.ibge.gov.br/brasil/pb/pedra-lavrada/panorama >. Acesso em: 19 de maio de 2018

JATOBÁ, L. Um pouco da história das condições climáticas do trópico semiárido brasileiro. Revista Cadernos de História, Universidade Federal do Pernambuco, Recife, v. 8, número 8, 2012.

JATOBÁ, L. A dialética das condições climáticas do semiárido nordestino brasileiro. Revista Equador (UFPI), Vol.5, nำ, p. 75 - 86 (Janeiro/Junho), 2016.

MARTINS, E. S. P. R.; MAGALHÃES, A. R. A seca de 2012-2015 no Nordeste e seus impactos.

Revista Parcerias Estratégicas - Edição especial CNCTI - • v. 20 •n. 41 • p. 107-128 • jul-dez 2015.

OLIVEIRA, J. S. ; TENÓRIO, J. C. S.; ARAÚJO, M. S. L. C. O reuso das águas cinzas no projeto bioágua: benefício para o meio ambiente e para o agricultor. Revista de Estudos Culturais e da Contemporaneidade, N. ${ }^{\circ} 18$ - Setembro/Outubro - 2017. https://doi.org/10.13115/22361499v2n18p497

POBLETE, C. P. C. Estudio del comportamiento de una mezcla de aserrín y grasa láctea de desecho. Valdivia: Universidad Austral de Chile, 2010.

SAMPAIO, Y. S. B.; ARAÚJO, E.V.S.B., ARAÚJO, M. S. B. Impactos ambientais da agricultura no processo de desertificação no nordeste do Brasil. Revista de Geografia, UFPE, V. 22, N. 1, Recife, 2005.

SANTIAGO, F. dos S. [et al.]. Bioágua Familiar: reuso de água cinza para produção de alimentos no semiárido. Recife: Projeto Dom Helder Câmara, 2012.

SANTIAGO, F. dos S. [et al.]. Manual de implantação e manejo do sistema bioágua familiar: reúso de água cinza doméstica para a produção de alimentos na agricultura familiar do semiárido brasileiro. $1^{\text {a }}$ Edição, ATOS, Caraúbas, 194 f.; 2015. ISBN: 978-85-69539-01-8.

SANTOS, C. F. dos; MAIA, Z. M. G; SIQUEIRA, E. S. ROZENDO, C. A contribuição da Bioágua para a segurança alimentar e sustentabilidade no Semiárido Potiguar brasileiro. Sustentabilidade em Debate - Brasília, v. 7, Edição Especial, p.100-113, dez/2016.

https://doi.org/10.18472/SustDeb.v7n0.2016.18347

Recebido em: 26/09/2018

Aceito para publicação em: 26/11/2019 